Meta

Journal des traducteurs

Translators' Journal

\title{
Innovation and Inspiration
}

The Development of Inuktitut Syllabic Orthography

\section{Kenn Harper}

Volume 38, numéro 1, mars 1993

La traduction et l'interprétation dans le nord du Canada

Translation and Interpretation in Northen Canada

URI : https://id.erudit.org/iderudit/003027ar

DOI : https://doi.org/10.7202/003027ar

Aller au sommaire du numéro

Éditeur(s)

Les Presses de l'Université de Montréal

ISSN

0026-0452 (imprimé)

1492-1421 (numérique)

Découvrir la revue

Citer cet article

Harper, K. (1993). Innovation and Inspiration: The Development of Inuktitut Syllabic Orthography. Meta, 38(1), 18-24. https://doi.org/10.7202/003027ar
Résumé de l'article

Vers 1850, deux missionnaires en poste à la Baie de James, J. Harden et E A. Watkins, entreprirent d'adapter à l'inuktitut l'orthographe syllabique cri de James Evans. En 1855, le système d'écriture syllabique fut présenté aux ¡nuit de Fort George et de Petite Rivière à la Baleine. Cette même année, un petit manuel des Saintes Écritures fut imprimé en syllabique à Moose Factory. En 1865, Harden et Watkins se rencontrèrent et modifièrent ce système d'écriture afin de pouvoir rendre plus fidèlement, à la fois, $\mathrm{V}$ inuktitut et le cri. L'orthographe inuktitut ne devait subir que des changements mineurs avant la révision en profondeur entreprise dans les années 1970 par la direction de l'Institut culturel inuit.
Ce document est protégé par la loi sur le droit d'auteur. L'utilisation des services d’Érudit (y compris la reproduction) est assujettie à sa politique d'utilisation que vous pouvez consulter en ligne.

https://apropos.erudit.org/fr/usagers/politique-dutilisation/ 


\title{
INNOVATION AND INSPIRATION - THE DEVELOPMENT OF INUKTITUT SYLLABIC ORTHOGRAPHY
}

KENN HARPER

Iqaluit, Northwest Territories, Canada

\begin{abstract}
Résumé
Vers 1850, deux missionnaires en poste à la Baie de James, J. Horden et E.A. Watkins, entreprirent d' adapter à l'inuktitut l'orthographe syllabique cri de James Evans. En 1855, le système d'écriture syllabique fut présenté aux Inuit de Fort George et de Petite Rivière à la Baleine. Cette même année, un petit manuel des Saintes Écritures fut imprimé en syllabique à Moose Factory. En 1865, Horden et Watkins se rencontrèrent et modifièrent ce système d'écriture afin de pouvoir rendre plus fidelement, à la fois, l' inuktitut et le cri. L'orthographe inuktitut ne devait subir que des changements mineurs avant la révision en profondeur entreprise dans les années 1970 par la direction de l'Institut culturel inuit.
\end{abstract}

\begin{abstract}
In the 1850's John Horden and E.A. Watkins, missionaries of the Church Missionary Society (CMS) to James Bay, began the work of adapting James Evan's Cree syllabic orthography to Inuktitut. Watkins' introduced the syllabic writing system to Inuit at Fort George and Little Whale River in 1855, and that same year Horden printed a small book of scripture verses in syllabics on his press at Moose Factory. In 1865, at the request of CMS Secretary Henry Venn, Horden and Watkins met in conference in England and modified the syllabic system to allow a more precise rendering of both Inuktitut and Moose Cree. It remained for Edmund James Peck, who arrived in the diocese in 1876, to devote his attention to the translation of scripture into Inuktitut in Horden and Watkins' orthography. Only minor changes were made in the Inuktitut orthography until the major revision under the direction of the Inuit Cultural Institute in the 1970's.
\end{abstract}

Inuit of the eastern Canadian Arctic cling tenaciously to a syllabic writing system used for over a century. The invention of white missionaries, Inuit by now regard it as their own and vigorously resist attempts to have it replaced by Roman orthography.

The syllabic writing system in use among Cree and Inuit today was the invention of a Wesleyan missionary, James Evans. Working originally in southern Ontario, he devised a system of nine symbols, each of which could be written in four different positions, to represent the vowel and consonant combinations of Ojibway. His mission board, however, refused him permission to use his creation. In 1840 Evans transferred to Norway House in what is now Manitoba, and it was there that he re-examined his syllabic orthography and modified it to suit the needs of Cree speakers. The results were amazing. The syllabic system could be learned in a few hours, and each new learner became a teacher to his fellows. Literacy in the syllabic orthography spread rapidly as far as the Rocky Mountains. Evans became known as "the man who made birchbark talk."

David Anderson, Bishop of the Diocese of Rupert's Land, was a critic of Evans' syllabic system. In 1849 he wrote:

The Wesleyans... have, very unfortunately... adopted a new character, the invention of the late Mr. Evans... He used, if I am rightly informed, four leading characters. By turning these 
to the right hand or to the left, or placing them upwards or downwards, they made sixteen letters: these, with some points and accents, complete the alphabet. A few of the Indians can read by means of these syllabic characters; but if they had only been taught to read their own language in our letters, it would have been one step towards the acquisition of the English tongue."

Two years later, John Horden, a school teacher, arrived at Moose Factory with his wife. He had familiarized himself with Evans' syllabic orthography even before his arrival, having studied it aboard ship on his Atlantic crossing. On his arrival Horden, who had come as a missionary, began to study Cree and to produce written material in syllabics for the Indians of the district. The results of his work so impressed Anderson that he became a supporter of the system he had earlier criticized so strongly.

In 1852, the Reverend Edwin Arthur Watkins arrived at Moose Factory. Bishop Anderson had decided to extend missionary work to the Inuit of lower Hudson Bay, and sent Watkins to Fort George with instructions to minister to the Indian population there as well as to whatever Inuit he could meet. It was not until the spring of 1853 that Watkins met his first Inuit, a group of four who had come to trade. One of the Inuit, a teenager named Peter, remained with Watkins, and Watkins spent "an hour each day with him, teaching him to read his own language and striving to gain some insight into it myself."

Watkins did not like the syllabic orthography. In reference to its work among the Indians, he wrote to the Church Missionary Society:

In teaching the Indians I have uniformly adhered to the Syllabic characters invented by $\mathrm{Mr}$. Evans, though I cannot say that further acquaintance has given me any high opinion of their value, indeed it is a question in my own mind whether it would not be better altogether to abandon them, and introduce a system of letters in their stead. The Syllabic system as I have it is certainly very defective and as my wish to discontinue its use may perhaps be thought to indicate prejudice or a want of perseverance, I will state some of its defects." After outlining the problems he saw with the system, Watkins continued: "When these things are considered I think it will be allowed either that there should be considerable additions made to the system, or that it should be altogether dispensed with and a better substituted... I cannot with any comfort write words in such a barbarous manner. Neither do I think that this way of writing is acquired so quickly by the Indians as its friends would make it appear... Even if this system should be well acquired, I think that sooner or later it will be set aside, and an alphabetic character be introduced..."

Horden was shocked at Watkins' views, and conferred with him in the summer of 1853. He appears to have convinced Watkins to continue using the syllabic writing system for his Indian work, but no decision had been reached on its use for Inuktitut, for Horden wrote in September of that year: "We have agreed to a slight modification of the CMS Standard of Orthography, when using the English letters in translations to enable him to adopt it in writing the Esquimaux." Watkins returned to Fort George and continued his Eskimo work using a Roman orthography. In 1855, however, he showed the syllabic script to Inuit from Little Whale River who were visiting Fort George, a decision he says he reached "after a great deal of hesitation." One can only see the continued influence of John Horden in this decision. Indeed, later that year, Horden wrote to CMS that "Mr. Watkins has introduced the Syllabic characters among the Esquimaux and I have now a book in that language to print for him." Even Horden recognized the limitations of the system, used without modification, for Inuktitut, for he wrote: "It is certainly a very great strain on the system, as the syllables are in a large proportion short syllables, many ending with two consonants; however, by the introduction of a few new characters, I think it can be managed tolerably, as the words of some six or seven syllables and thirty 
letters will not when written in the syllabic characters present that formidable appearance which they do in the Roman Characters."

Horden had his own printing press at Moose Factory and in 1856 he printed a small book in syllabic script in Inuktitut for Watkins. Watkins wrote in his journal: "I received... from Moose some selections from the Gospels in Esquimaux, printed in the Syllabic character. The books... do not contain the whole text I had written out, and the deficiency of type for many of the final consonantal sounds will cause some trouble to be taken with the pen..." No copies of this book, the first known to have used Inuktitut syllabics, has survived. It is likely that its contents were transliterations into syllabics of verses from the Moravian Brethren's 1840 publication of the New Testament in the Labrador dialect.

By now it was recognized that the syllabic system would need revision if it were to be used with ease for the writing of Inuktitut.

In 1857 the Hudson's Bay Company closed its Fort George post and Watkins transferred to Red River, moving again the following year to Cumberland Station, effectively leaving his Inuktitut work behind him. He resigned and returned to England in 1863. After 1857 work among the Inuit of the Eastmain was sporadic. Horden did what he could from Moose Factory. In 1859 the Reverend T.H. Fleming spent four months at Little Whale River, the purpose of his visit being "to teach [the Inuit] to read the syllabic characters, which in so short a time are learned, and then to place in their hands rolls containing the Lord's Prayer and Ten Commandments and brief portions of scripture..." He noted that: "I do not after all think the Syllabic system so badly adapted to their language. I know that there are difficulties connected with it, but if they had them clearly explained, I believe they might be easily overcome. The chief difficulty is the number of consonants in their words." In 1862 Horden again visited Little Whale River. While there he translated "Watts's First Catechism" into Inuktitut. In 1865 he sent it to England for publication. For some reason it was not published until 1869 ; it is the first publication in Inuktitut syllabics to have survived.

In the meantime an event of considerable importance occurred, a result of the many comments on the inadequacies of the Cree syllabic system to represent the sounds of the Inuktitut language. In 1864, Henry Venn, secretary of the Church Missionary Society, decided that the syllabarium should formally be adapted to the Eskimo language. He suggested that a conference of Horden, Watkins and Joseph Phelps Gardiner (a missionary with experience among the Inuit at Churchill) be held "to promote an important object, the fixing of the Esquimaux language." By letter he informed Horden that Gardiner had made little progress with Inuktitut language and Watkins a little more, "but Mr. Watkins and Mr. Gardiner differ in their Syllabic orthography, the latter having adopted Mr. Hunt's new symbols. The Committee determine therefore to take advantage... of the presence of so many of our... missionaries next autumn to settle, as far as we may be able to do, the orthography for as much of the language as our materials will reach."

Venn's reference to Mr. Hunt's new symbols requires some explanation.

In 1851 Robert Hunt had established the Stanley Mission on the English River in what is now Saskatchewan, for the Church Missionary Society. He began almost immediately to experiment with Evans' syllabic orthography in use among the Cree there. He suggested a revision, the use of a superscript character of the same shape as that of the main syllabic characters to represent syllable-final consonants. He observed that "the last thing the Indians master... is the plan of representing the final consonants." If the main characters were used, but in a smaller type, he concluded that "this would... as far as I can see, reduce the difficulty to nothing, for the initials once learnt, the finals are also known..." 
Hunt preferred to follow Evans' method of representing long vowel sounds by using thickened strokes on characters or portions of characters, although Horden had adopted the convention of representing a long vowel sound by a dot over a symbol.

Robert Hunt continued his revisions of Evans' syllabic orthography at his post at Stanley Mission until he retired in 1862 , eventually revising it until it bore little resemblance to Evans' original work. He suggested that his modifications made syllabics suitable for writing all the languages of the world. By 1856 he had created a complex system which he called the "American Indian Phonetic Syllabic Scheme." In that year, despite the opposition of his superior, Archdeacon James Hunter, CMS published a 52-page book in Hunt's orthography. By 1861, a year before his resignation, he had revised his orthography still further and was referring to it as the "Phonocamptic Syllabic Scheme."

On Hunt's way home to England in 1861 he met Reverend Joseph Phelps Gardiner at York Factory. Gardiner transferred shortly afterwards to Churchill where he worked with Indians and Inuit. He wrote to the CMS secretary from there that "I have adopted Mr. Hunt's system of Syllabics. It is much more simple and expressive than the Norway House system... Mr. Hunt's will [do] also for the Eskimo."

The conference that Venn had called on the future of the syllabic system among the Inuit finally occurred in 1865, but without Gardiner's presence. Horden and Watkins met in England to decide on modifications necessary in both the Cree and Inuktitut syllabaries. The minutes of their conference were signed on 24 November 1865 and are as follows:

1. It appears to us very undesirable that any changes, except such as are absolutely necessary, should be made in the Syllabarium as now used; though we quite agree that the system is not so scientifically accurate as could be wished. We consider that in dealing with the uncultivated tribes of North America, utility and simplicity are of more importance than philological precision.

2. In reducing the Esquimaux language into syllabic writing, we think that a change may be advantageously made in the final symbols. Instead of the arbitrary signs now in use for the Cree, we would propose the adoption of half-size characters of the same forms as those employed for the consonants in combination with the vowel $a$. This change might be introduced into the Cree language at a future period; but as there is in existence a large supply of Bibles and other publications printed according to the original method, we would not advocate any alteration at present.

3. The additional consonants, $b$ and $d$, found in the Esquimaux, may, we think, be represented with sufficient accuracy by the characters for $p$ and $t$ respectively, without the introduction of new forms; especially as the natives frequently pronounce these letters so indistinctly that it is difficult to ascertain their true sound.

4. In the Esquimaux language there are some double consonants which will need to be represented. For these we have adopted signs which combine as nearly as possible the two separate consonants.

The major innovation in the revision to syllabics for Inuktitut was the second one, dealing with the problem of representing syllable-final consonants. The solution adopted by Horden and Watkins was nearly identical to that proposed by Robert Hunt twelve years earlier. He had proposed the use of superscript characters bearing the same shape as the main characters, although he chose them at random from the columns of main characters. Horden and Watkins took their inspiration from Hunt's work, but chose to use the main characters of the fourth column in a superscript position.

Some years later Horden wrote a letter which made it plain that he was not enthusiastic about the revisions that he and Watkins had published. In a letter to London in 1875 , 
he remarked that "If the correction and improvement of the Syllabarium had been undertaken by me, as an individual, I would not say a word in its favour. I wished for no change, and only undertook the duty, in conjunction with Watkins, at the request, or rather command of Mr. Venn, who approved of the work, when we had completed it." This may explain why Horden's translation of "Watts's First Catechism", published finally in 1869, used Evans' original Cree finals instead of the finals approved for use in Inuktitut in 1865. It may, alternatively, reflect only the fact that Horden did not revise the text, which he had sent to England for publication some time before the conference.

In 1876 Horden's long-standing request for a missionary to minister primarily to the Inuit was answered with the arrival of Edmund James Peck at Little Whale River. Peck made very minor revisions to the syllabic orthography in use among Inuit. Although it is often stated that Peck adapted Evans' Cree syllabics to the Inuktitut language, such is not the case - the bulk of the work had been done by Horden and Watkins. Peck's major contribution to mission work and to literacy among the Inuit was the translation of the Gospels and other Church literature and seeing the completed works through the press. He devoted the next four decades of his life to this task.

One of the major inconsistencies in the use of syllabics since the time of Peck has been the representation of long vowel sounds. Although Horden had suggested that "a dot over a symbol gives a longer vowel sound," the missionaries were in fact attempting to represent the differences between the English-language conception of long and short vowels, in reality a difference in the quality of the vowel, whereas what is significant in Inuktitut is the actual length of time that the vowel sound is held. Syllabics were introduced to the Inuit of the Keewatin by the Roman Catholic missionary, Father Turquetil, in 1912, but the Catholics treated vocalic length in a different manner still, choosing to use a main character from the first series (ai, $i, u, a)$ after another main character to lengthen the vowel sound of that main character.

In the 1950s and 1960s the Department of Northern Affairs and National Resources turned its attention to the necessity for a "common written language which would, in a near future, encompass the extensive Canadian Eskimo domain...", "a native, supradialectical written means of communication." Gilles Lefebvre and Raymond Gagné, linguists employed by the department, opted for a gradual phasing out of syllabics and the introduction of a new Roman alphabetic writing system. In Gagné's analysis of syllabics, he considered the old problem of the representation of syllable-final consonants:

One might argue that... a small post-syllabic symbol, prescribed by certain missionaries, standing for the single consonant... could maintain the distinction. A brief glance at any publication which uses the secondary syllabic symbols will easily illustrate the complexity of such a practice, keeping in mind the minuteness of such symbols and the difficulty of reproducing them by hand at the upper right of the ordinary syllabic. They are very seldom used by the Eskimo people themselves."

Gagné had over-simplified the problem. Mark Kalluak, editor of the Keewatin Echo, helped to clarify the situation when he wrote in 1976:

For a long time I never bothered to use the finals... It was only when I started publishing Inuktitut newspapers that I realized the importance of using the finals and other characters that lengthen or shorten certain sounds in words. I may even use them too much today, of course, because they are necessary to get the proper meaning of the words.

Ironically, Gagné, in rejecting syllabics, concluded that, nevertheless, "the syllabary follows the phonemic principle recommended by the majority of modern linguists as the 
soundest principle on which to base a system of writing," and "the syllabary is far closer to a phonemic orthography than either French or English spellings or any of the alphabets thus far devised for writing Eskimo." Nonetheless Gagné concluded that "the syllabary is inaccurate" and "in the final analysis, it must either be improved or discarded."

Although Gagné suggested the idea that syllabics could be improved, he never seriously pursued the possibility. The department proceeded with the development of a standard Roman orthography. Despite the best efforts of the department, the new system never caught on. Gagné had seriously underestimated Inuit attachment to their syllabic orthography when he wrote: "...I do not believe that the Eskimo are sentimentally attached to their syllabics as many Englishmen and Frenchmen are to their spelling." Mark Kalluak spoke for many Inuit when he wrote in 1976: "When I became fully familiar with the use of syllabics, I became, as it were, in love with them, even so far as to defend their use if someone wasn't pleased with the way I write, or hinted I was wrong... Some Inuit do not want to give up syllabics simply because they're different and it makes them appear to be genuine Inuk; some perhaps even think that syllabics was invented by Inuit."

By the 1970s the need for a reform of the syllabic writing system had been recognized by Inuit themselves. In May of 1972 a seminar was held in Rankin Inlet to discuss what form of syllabic writing to use in two booklets being prepared for the primary grades in Whale Cove. The results were a breakthrough in the development of syllabics:

The delegates agreed that syllabics be used with all the finals, with... the following:

"A dot placed over a letter to indicate long vowel..."

"Omit all the first letters in the syllabic alphabet... [that is, the first column]."

"Omit small $o$ placed over a letter to change the sound $i$ to ai."

"Also [omit] a small $o$ placed between the letters to make a sound $d . . . "$

The results of this conference represented largely the influence of two pioneer Inuit linguists, Mark Kalluak, adult educator and newspaper editor, and Armand Tagoona, who was the first Inuk to be ordained into the Anglican clergy. Both had long recognized the need for a standardization in the use of syllable-final consonants and the representation of long vowels. Both also recognized the inconsistency with which the Anglican church represented long vowel sounds. Kalluak used the Keewatin Echo, a monthly newspaper, as a forum for discussion on the need for syllabic reform; Tagoona, who broke away from the Anglican church and established his own fellowship in Baker Lake, used his church and his influence as a venue for a similar discussion. Their contributions were recognized in 1974 when Eric Anoee of Eskimo Point wrote: "Tagoona and Mark are the only ones in the Keewatin area who use syllabics in a suitable way through printed material. Personally I go along with their translations, and I agree with what they have written and how they use syllabics... I have been concerned about syllabics for as many as forty years... I want syllabics to have meaning and be able to express a word."

The stage had been set for the Inuit Language Commission, proposed and sponsored by Inuit Tapirisat of Canada and funded in 1974 by the federal Department of Indian and Northern Affairs. The second of its seven objectives was to "study the present state of the written language and recommend changes for the future." Jose Kusugak of Rankin Inlet was appointed Executive Director of the commission.

The result was the development of a dual orthography. A Roman orthography was devised, built on an analysis of the language and the application of scientific principles to guide the development of the writing system. It drew heavily on the earlier work of Raymond Gagné. The committee decided to keep orthographic innovations in syllabics to a minimum and that no new symbols would be introduced unless absolutely necessary. The syllabic system was standardized and made completely compatible with the Roman 
system. Because the two orthographies were based on a single analysis of the language and its orthographic needs, it was in fact one system with two orthographic forms. The revision to syllabics dealt adequately with the issue of vowel length and with the representation of syllable-final consonants. In fact, the orthography which resulted, for syllabics, differed little from that which had stemmed earlier from the Rankin Inlet education workshop in 1972.

The dual orthography was ratified by the Inuit Language Commission at a meeting in Frobisher Bay in August of 1976.

Each orthographic form was given its own name in Inuktitut - qaliujaaqpait for the Roman orthography, and qaniujaaqpait for syllabics.

Inuit of the Eastern Arctic are still devoted to the use of the syllabic writing system. New computer technology has made it easier to use syllabics in publishing and the system is used extensively in schools in the Northwest Territories and Arctic Quebec. The 1976 revisions to the syllabic orthography have been the most completely accepted in the Keewatin, where Inuit themselves pioneered the work of syllabic reform, and, ironically, the least so in Arctic Quebec where Horden and Watkins pioneered the work over a hundred years ago. 